Halaman: 77-83

\title{
Daya Hambat Ekstrak Etanolik Buah Sirih Hijau (Piper betle L.) Terhadap Pertumbuhan Jamur Candida albicans (ATCC 1805)
}

\author{
ESTHER RAMPA \\ Staf Pengajar Universitas Sains dan Teknologi Jayapura (USTJ), Papua \\ Diterima: tanggal 21 Juli 2013 - Disetujui: tanggal 27 September 2013 \\ (C) 2013 Jurusan Biologi FMIPA Universitas Cenderawasih
}

\begin{abstract}
The research had been conducted in the Laboratory of Microbiology, Department of Biology, Faculty of Mathematics and Natural Sciences, the University of Cenderawasih during September-November 2012. The aims of the research were to understand the effect of green betel fruit extract inhibition against the C. albicans, as well as the effective concentration of extract to inhibit the growth of the fungus. Fruit samples were obtained from the Koya Koso village, Abepura District, Jayapura city, while the fungal isolates of C. albicans was obtained from the Laboratory of Microbiology, Faculty of Medicine, University of Padjadjaran. The study was performed using a method of disk diffusion method with concentration of $10 \%, 5 \%, 2.5 \%$ and control, while indicator parameter were measured based on the presence of inhibition zone caused by inhibition treatment. The study was designed on a Completely Randomized Design (CRD) and the data were analyzed using analysis of variance at $\alpha=0.5$ and $\alpha=0.1$. The presences of significant differences of data were further analyzed using Least Significance Differences (LSD) analyses. The results showed that all green betel fruit extract concentrations effectively inhibited the growth of the fungus $C$. albicans and concentration of $10 \%$ revealed the best inhibition effect.
\end{abstract}

Key words: Inhibitory effect, Piper betle L, fruit extract, fungus.

\section{PENDAHULUAN}

Penyakit infeksi merupakan penyakit yang disebabkan oleh mikroorganisme, misalnya virus, bakteri, protozoa, cacing, dan jamur. Salah satu yang sering menyebabkan penyakit pada manusia adalah infeksi jamur. Kandiasis merupakan salah satu penyakit kulit, kuku dan selaput lendir yang disebabkan oleh infeksi beberapa jenis Candida spp. Penyakit ini dijumpai terdapat di seluruh dunia, menyerang semua umur baik laki-laki maupun perempuan. Hingga saat ini diidentifikasi sebanyak 150 jenis kandida, 70\% diantaranya menginfeksi manusia (Kuswaji et al., 1999).

Menurut Adams et al. (2011) penyakit yang

*Alamat korespondensi:

Jurusan Ilmu Lingkungan, Fakultas Ilmu Kesehatan, USTJ, Jayapura. Jl. Sentani, Padangbulan, Abepura-Jayapura, Papua. Kode Pos: 99581. e-mail: e-rampa@yahoo.co.id diakibatkan oleh jamur secara medik sangat serius bagi kehidupan manusia. Selain Candida albicans, beberapa fungi lain seperti Cryptococcus albidus, C. neoformans, dan Rhodotorula merupakan jenis jamur yang umum dijumpai menginfeksi manusia.

Kandida yang menginfeksi didominasi oleh jenis C. albicans dan sisanya adalah jenis lain (Kuswadji et al., 1999). Kejadian kandidiasis di Indonesia dilaporkan pada tahun 2003 yang mencapai sekitar 85 sampai $90 \%$. Jenis kandida yang paling banyak ditemukan dan mempunyai prevalensi tinggi adalah C. albicans yaitu sekitar $81 \%$ pada organ genital utamanya vagina, $16 \%$ Torulopsis glabarata, dan sisanya $3 \%$ disebabkan oleh C. tropicalis, C. crusei, C. stellatoidea, dan Pseudotropicalis sp (Darmani, 2003). Tingginya prevalensi oleh $C$. albicans disebabkan karena jamur ini menginfeksi berbagai organ tubuh baik permukaan bagian luar maupun organ dalam 
tubuh pada manusia (Darmani, 2003; Agarwal et al., 2008).

C. albicans merupakan jamur komensal yang secara normal hidup di mukosa manusia maupun hewan. Kandida adalah anggota flora normal terutama saluran pencernaan, juga selaput mukosa saluran pernafasan, vagina, uretra, kulit, dan di bawah jari-jari kuku tangan dan kaki. Pada bagian-bagian ini kandida dapat menjadi dominan dan menyebabkan kondisi patologik ketika daya tahan tubuh menurun. Dilaporkan juga bahwa kandida menyebabkan penyakit sistemik progresif pada penderita yang lemah atau dapat mengganggu sistem imum yang rendah (Jawetz \& Adelberg, 2008; Agarwal et al., 2008). Kandida dapat menyebabkan septikimia atau masuk ke dalam aliran darah, tromboflebitis, endocarditis, infeksi pada bagian mata. Selain itu, dapat pula dijumpai pada organ-organ lain bila menggunakan peralatan medis yang tidak' steril secara intravena (kateter, jarum, hiperalimentasi, penyalahgunaan narkotika, dan sebagainya (Jawetz \& Adelberg, 2008).

Pengobatan terhadap penyakit yang disebabkan oleh jamur (mikosis) selama ini dilakukan dengan cara kimia menggunakan antijamur dan obat tradisional. Perkembangan obat antijamur masih terbatas, berbeda dengan antibakteri yang berkembang lebih pesat. Hal ini ditunjukkan dengan diproduksinya berbagai macam obat antibakteri setiap tahun (Siswandono \& Soekardjo, 1995). Keputusan Menteri Kesehatan No.381/2007 tentang anjuran penggunaan obatobat tradisonal secara alamiah (back to nature) menjadi penting karena dapat mengoptimalkan pemanfaatan sumber daya alam yang ada di Indonesia. Tumbuhan obat tradisional menjadi sumber pengobatan yang efektif di kalangan masyarakat utamanya yang tinggal di kampung atau daerah terpencil dengan kondisi ekonomi lemah. Sekitar $80 \%$ dari populasi manusia di dunia, masih memanfaatkan tumbuhan sebagai obat tradisional (Syukur \& Hermani, 1999; Ragu, 2010). Salah satu tumbuhan yang digunakan sebagai obat tradisional, bahkan sudah dikomersialkan dalam berbagai produk adalah tanaman sirih khususnya ekstrak daun sirih (Piper $\mathrm{sp)}$.

Selama ini telah dilakukan penelitian daya hambat ekstrak daun sirih terhadap berbagai penyebab infeksi termasuk bakteri. Bahkan telah dibuat ekstrak untuk obat kumur, pasta gigi, dan ekstrak pembersih organ genital wanita. Buah sirih hijau yang dibudidayakan di Papua sering dikonsumsi oleh kalangan masyarakat Papua mulai dari anak-anak hingga orang dewasa. Berdasarkan hal tersebut, maka perlu dilakukan penelitian mengenai efek ekstrak buah sirih hijau khusususnya terhadap daya hambat pertumbuhan C. albicans.

\section{METODE PENELITIAN}

Penelitian ini dilaksanakan di Laboratorium Mikrobiologi Jurusan Biologi FMIPA, Universitas Cenderawasih Jayapura selama bulan AgustusSeptember 2012. Sampel penelitian buah sirih hijau (Piper betle) diperoleh dari Koya Koso, Distrik Abepura, Kota Jayapura, sedangkan isolat C. albicans (ATCC 1805) diperoleh dari Laboratorium Mikrobiologi, Fakultas Kedokteran Universitas Padjajaran (Unpad), Bandung. Ekstraksi sampel buah sirih dilakukan dengan etanol 70\%. Hasil ekstraksi digunakan untuk perlakuan dalam penelitian ini (Hermawan et al., 2007; Rahmah \& rahman, 2010).

Rancangan penelitian yang digunakan adalah rancangan acak lengkap (RAL) 4 perlakuan dengan 4 kali ulangan. Konsentrasi yang digunakan adalah K3 (10\%): 0,5 ml ekstrak buah sirih + 4,5 ml dimetyl sulfoksida (DMSO) 10\%, K2(5\%): 0,25 ml ekstrak buah sirih + 4,75 ml DMSO 10\%, dan K1 (2,5\%) 0,125 ml ekstrak buah sirih $+4,875 \mathrm{ml}$ DMSO 10\% dan (K0) kontrol fluconazol. Analisis data dilakukan dengan analysis of variance (ANOVA) dan jika diketahui terdapat perbedaan signifikan dilanjutkan dengan uji BNJ pada taraf $a=0.01$ (Steel \& Torrie, 1991).

Metode kerja yang digunakan adalah metode difusi disk. Perlakuan diinkubasi 24 jam pada medium saboroud dexrtose agar (SDA). Disk blanck direndam ke dalam setiap konsentrasi 
ekstrak buah sirih selama 30 menit. Setelah 30 menit disk diambil dengan pinset kemudian diletakkan ditengah cawan petri yang telah diinokulasi dengan jamur C. albicans dengan cara tabur menggunakan ose bengkok. Selanjutnya diinkubasi selama 24 jam pada suhu $37{ }^{\circ} \mathrm{C}$. Parameter yang diamati adalah adanya zona hambat atau bening. Pengukuran diameter zona hambat dengan menggunakan jangka sorong.

\section{HASIL DAN PEMBAHASAN}

Hasil pengujian ekstrak buah sirih hijau terhadap respon pertumbuhan C. albicans secara in vitro menunjukkan bahwa semua konsentrasi ekstrak buah sirih hijau, dan kontrol fluconazol dapat memberikan respons positif terhadap pertumbuhan C. albicans (Gambar 1).

Tabel 1 menunjukkan rata-rata diameter zona hambat ekstrak buah sirih hijau terhadap $C$. albicans setelah diinkubasi 24 jam pada medium SDA. Rerata diameter zona hambat pada konsentrasi $2.5 \%, 5 \%, 10 \%$ dan flukonazol yaitu 17,$35 ; 19,38 ; 25,88$ dan $8,48 \mathrm{~mm}$. Rata-rata zona hambat yang dihasilkan menunjukkan bahwa semua perlakuan konsentrasi memberikan zona hambat yang berbeda dalam menghambat pertumbuhan jamur C. albicans. Hasil ini menunjukkan bahwa semakin tinggi konsentrasi perlakuan yang digunakan, semakin tinggi pula kemampuan ekstrak buah sirih dalam menghambat pertumbuhan C. albicans (Gambar 2). Kemungkinan adanya peningkatan daya hambat pada konsentrasi lebih tinggi masih memungkinkan. Walaupun dalam penelitian ini tidak dilakukan, dari grafik (Gambar 2) menunjukkan terjadinya peningkatan yang lebih baik dengan semakin tingginya konsentrasi perlakuan.

Analisis ragam ekstrak buah sirih hijau pada taraf nyata $\mathrm{a}=0.05$ dan $\mathrm{a}=0.01$ dengan derajat bebas 3,12, pada tabel $F$ diperoleh nilai 3.59 dan 5.95 nilai tersebut menunjukkan hasil perlakuan sangat signifikan (Tabel 2), maka dilakukan uji lanjut dengan menggunakan uji beda nyata jujur (BNJ) untuk mengetahui konsentrasi yang efektif (Tabel 3).
Tabel 1 diperoleh hasil rerata zona hambat yang berbeda-beda dalam menghambat pertumbuhan C. albicans. Rerata zona hambat ekstrak buah sirih hijau adalah 17,35-25,88 $\mathrm{mm}$, hal ini membuktikan bahwa ekstrak buah sirih hijau dapat digunakan untuk mengobati penyakit jamur yang disebabkan oleh C. albicans, karena zona hambatnya terdapat diantara zona hambat yang dianjurkan. Menurut Hermawan et al. (2007) bahwa interpretasi daerah hambatan pertumbuhan antimikroba mengacu pada standar umum yang dikeluarkan Depkes (1988) disebutkan
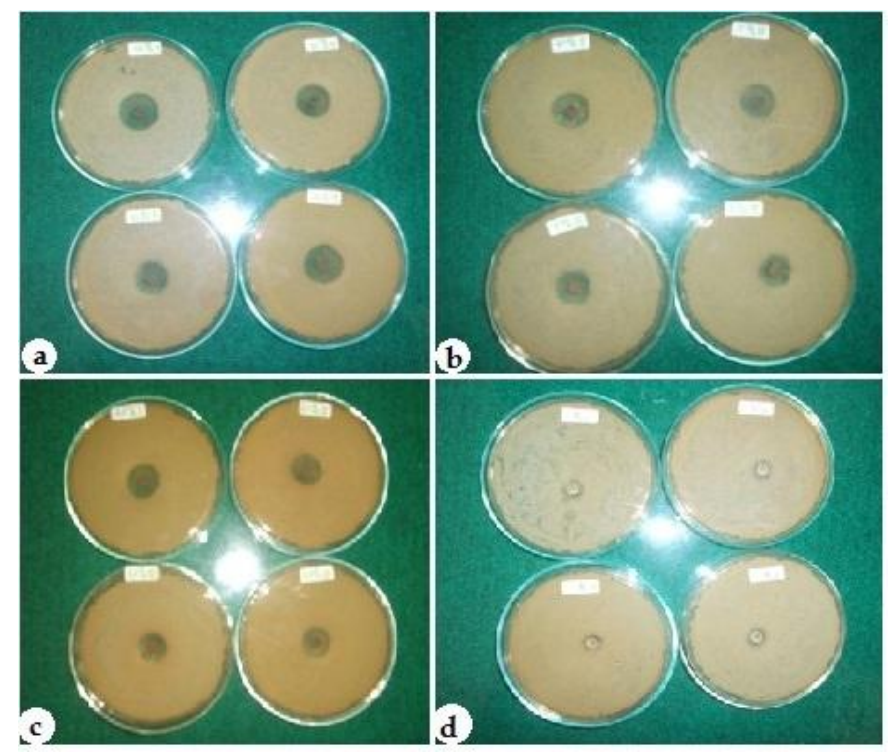

Gambar 1. Aktivitas penghambatan ekstrak buah sirih hijau terhadap pertumbuhan Jamur C. albicans (tanda panah). a. konsentrasi $10 \%(\mathrm{~K} 3)$, b. konsentrasi 5\% (K2), c. konsentrasi 2,5\% (K1), dan d. Kontrol flukonasol (K0).

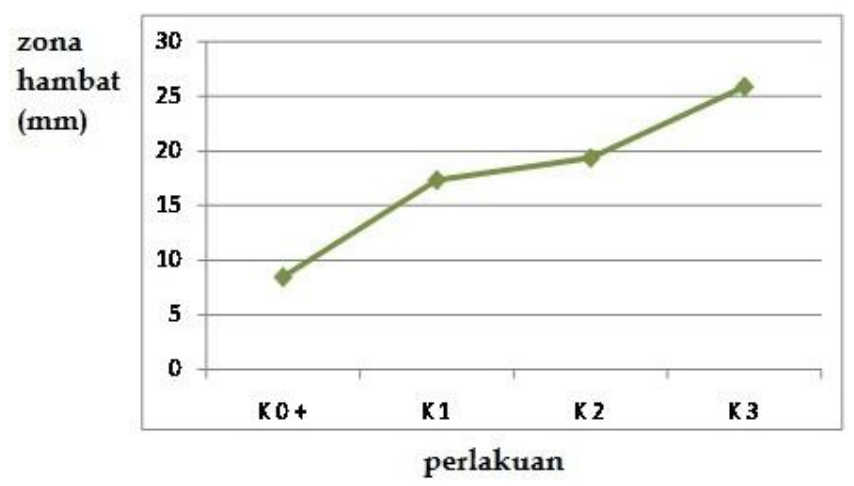

Gambar 2. Pengaruh ekstrak buah sirih hijau terhadap pertumbuhan C. albicans. Ket.: $\mathrm{K} 0=$ kontrol fluconazol, $\mathrm{K} 1=$ kosentrasi 2,5\%, $\mathrm{K} 2=$ konsentrasi 5\%, K3= konsentrasi 10\%. 
Tabel 1. Rerata diameter (mm) zona hambat dari ekstrak buah sirih hijau terhadap C. albicans.

\begin{tabular}{|c|c|c|c|c|c|}
\hline \multirow{2}{*}{$\begin{array}{c}\text { Perlakuan } \\
\text { Ulangan }\end{array}$} & \multicolumn{4}{|c|}{ Konsentrasi } & \multirow[t]{2}{*}{ Total } \\
\hline & K0 & K1 & K2 & K3 & \\
\hline 1 & 8.33 & 18.1 & 18.7 & 24.7 & \\
\hline 2 & 7.66 & 16.8 & 19.5 & 25.3 & \\
\hline 3 & 9.67 & 16.2 & 19,0 & 29.0 & \\
\hline 4 & 8.26 & 18.3 & 20.3 & 24.5 & \\
\hline Total & 33.9 & 69.4 & 77.5 & 103.5 & 283.87 \\
\hline Rerata & $8.48 \mathrm{a}$ & $17.35 \mathrm{~b}$ & $19.38 \mathrm{~b}$ & $25.88 \mathrm{c}$ & \\
\hline
\end{tabular}

Ket.: $\mathrm{K} 0=$ Kontrol fluconazol, $\mathrm{K} 1=$ kosentrasi $2.5 \%, \mathrm{~K} 2=$ konsentrasi $5 \%, \mathrm{~K} 3=$ konsentrasi $10 \%$. Huruf yang berbeda pada baris rerata menunjukkan perbedaan signifikan pada uji.

Tabel 2. Hasil analisis ragam perlakuan ekstrak buah sirih hijau.

\begin{tabular}{lrrrccc}
\hline Sumber & $\begin{array}{l}\text { Derajat } \\
\text { Bebas }\end{array}$ & JK & KT & $\mathrm{F}_{\text {hit }}$ & \multicolumn{2}{c}{$\mathrm{F}_{\text {Tabel }}$} \\
\hline Variasi & & & & & 0.05 & 0.01 \\
Perlak. & 3 & 618.99 & 206.33 & 123.3 & 3.59 ss & $5.95^{\text {ss }}$ \\
Galat & 12 & 20.08 & 1.67 & & & \\
Total & 15 & 639.08 & & & & \\
\hline
\end{tabular}

Tabel 3. Beda dua rerata konsentrasi perlakuan ekstrak buah sirih hijau terhadap C. albicans dengan $B N J a=$ 0.01 .

\begin{tabular}{cccccc}
\hline Perlakuan & Signifikansi & \multicolumn{3}{c}{$\begin{array}{c}\text { Beda dua rerata } \\
\text { perlakuan }\end{array}$} & $\begin{array}{c}\text { BNJ } \\
0,01\end{array}$ \\
\hline K0 & 8.48 & a & & \\
K1 & 17.35 & $9.02 \mathrm{~b}$ & & \\
K2 & 19.38 & $11.05 \mathrm{~b}$ & $2.03 \mathrm{~b}$ & & \\
K3 & 25.88 & $17.55 \mathrm{c}$ & $8.52 \mathrm{c}$ & $6.5 \mathrm{c}$ & \\
\hline
\end{tabular}

sebagai bahan uji penghambatan mikrobia. Ragu (2010) melaporkan zona hambat ekstrak daun sirih terhadap mikroorganisme disebabkan oleh minyak atsiri yang mengandung minyak terbang (betlephenol), seskuiterpen, pati, diatase, gula dan zat samak serta kavikol yang memiliki daya mematikan bakteri, antioksidan dan fungisidal. Hermawan et al. (2007) melaporkan bahwa karvakol pada daun sirih bersifat antijamur sehingga dapat digunakan sebagai antiseptic. Selain karvakol pada daun sirih juga terdapat eugenol dan methyl-eugenol yang dapat digunakan untuk infeksi gigi atau mengurangi sakit pada gigi.

Adanya perbedaan yang signifikan dari setiap perlakuan konsentrasi ekstrak buah sirih hijau (Tabel 1), jika dibandingkan dengan kontrol yang menggunakan fluconazole. Kon-sentrasi ekstrak buah sirih hijau pada K1 (2,5\%) dan K2 $(5 \%)$ secara statistik tidak terdapat perbedaan yang signifikan, kemungkinan disebabkan oleh senyawa antimikroba yang ada dalam buah sirih berbeda sangat kecil sehingga pengaruhnya terhadap pertumbuhan $C$. albicans tidak jauh berbeda. Konsentrasi ekstrak buah sirih hijau pada K3 (10\% berbeda sangat signifikan dengan konsentrasi K1 (2,5\%), K2 (5\%), dan KO (kontrol). Adanya

bahwa mikroba dikatakan peka terhadap antimikroba asal tumbuhan apabila mempunyai ukuran diameter daya hambat sebesar 12-24 mm. Ragu (2010) melaporkan bahwa ekstrak daun sirih mempunyai daya hambat terhadap C. albicans dengan rerata zona hambat $(16 \mathrm{~mm})$ dalam konsentrasi DMSO $100 \mu \mathrm{L} / \mathrm{ml}$. Menurut Rahmah \& Rahman (2010) konsentrasi 80\% dari ekstrak daun sirih sudah dapat menghambat pertunasan atau reproduksi sel-sel C. albicans tetapi belum mampu menghambat pertambahan masa tiap selnya.

Kajian mengenai aktivitas penghambatan dan kandungan kimia buah sirih masih minim, sebagian besar mengacu pada pemanfaatan daun perbedaan zona hambat antar perlakuan kemungkinan disebabkan semakin tinggi konsentrasi ekstrak buah sirih hijau. Semakin besar jumlah senyawa antimikroba yang terkandung di dalam buah sirih hijau, menyebabkan zona hambat semakin besar atau semakin efektif untuk menghambat pertumbuhan C. albicans.

Hermawan et al. (2007) dan Reveny (2012) mengungkapkan bahwa semakin tinggi konsentrasi ekstrak daun sirih yang digunakan, zona hambatnya semakin besar. Hal yang sama dilaporkan oleh Gholib \& Kusumaningtyas (2007) mengenai daya hambat ekstrak daun sirih terhadap jamur Trychophyton mentagrophytes yaitu 
semakin tinggi konsentrasi yang digunakan maka zona hambatnya semakin besar.

Hasil penelitian ini tidak didukung oleh pengamatan yang dilakukan oleh Effendy (2013). Menurut Effendy (2013) daun sirih merah tidak mampu mempengaruhi penghambatan C. albicans. Dalam penelitian tersebut, organ yang digunakan adalah daun sirih merah. Sedangkan hasil pengamatan yang dilakukan oleh Reveny (2011) cukup menguatkan bahwa hasil penelitian ini cukup berarti. Hasil penelitian yang dilakukan oleh Reveny (2011) diperoleh informasi bahwa konsentrasi penghambatan minimum pada daun sirih merah ektrak etanol $80 \%$ adalah $2,5 \%$ untuk S. aureus, $1 \%$ untuk E. coli dan $2,5 \%$ untuk $C$. albicans.

Senyawa hasil ekstrak dari tanaman Graptophyllum pictum berpengaruh terhadap pertumbuhan C. albicans pada plat gigi tiruan resin akrilik (Wahyuningtyas, 2008). G. pictum merupakan salah satu jenis tumbuhan obat yang masih dimanfaatkan oleh masyarakat hinga saat ini. Tumbuhan ini diketahui mengandung flavonoid, yang memberi efek sebagai antimikrobia.

Menurut Sulistijowati \& Gunawan (1998) perkembangan C. albicans juga dapat dihambat dengan ekstrak tanaman Tithonia diversifolia hasil ekstraksi fraksi etil asetat pada konsentrasi $80 \%$. Akan tetapi pada konsentrasi di bawahnya (40\%) pengaruh tersebut tidak nyata. Demikian pula hasil ektraksi dengan fraksi air tidak berpengaruh terhadap pertumbuhan C. albicans. Thirach et al. (2003) juga mengungkapkan beberapa ekstrak dari jenis tanaman mampu menghambat pertumbuhan C. albicans dan C. neoformans, diantaranya adalah ekstrak etanol dari tanaman Eugenia caryophyllus dan Acorus calamus. Sedangkan Supreetha et al. (2011) mengkaji aktivitas ekstrak tumbuhan obat Zingiber officinale, yang efektif dalam aktivitas antifungi khususnya penghambatan pertumbuhan C. albicans. Hal yang sama juga dilakukan oleh Erturk (2006) dan Doddanna et al. (2013) yang dilakukan dengan ekstrak etanol dari beberapa jenis tanaman diantaranya adalah Mellisa officinalis, Mentha piperita, Laurus nobilis, Dianthus coryophyllum, Piper nigrum, Capsicum annum, Juniperus oxyceratdrus, Erica arborea, dan Colutea arborencens. Masing-masing tumbuhan tersebut mempunyai pengaruh yang berbeda-beda terhadap mikroba.

Menurut Kumalasari \& Sulistyani (2011) hasil pengamatan yang dilakukan dengan ekstrak etanol batang binahong (Anredera cordifolia) menunjukkan kadar bunuh minimum (KBM) terhadap C. albicans adalah 86\%. Ekstrak tumbuhan binahong menggunakan pelarut etanol $70 \%$, sedangkan metode untuk pengamatan dilakukan dengan metode dilusi cair.

Damayanti \& Mulyono (2008) melaporkan bahwa aktivitas antijamur diduga berasal dari minyak atsiri daun sirih yaitu isoeugenol, limonene, $\beta$ - pinen dan kariofilena menghambat pertumbuhan $C$. albicans. Syukur \& Hermani (1999) melaporkan bahwa selain karvakol juga terdapat flavonoid, saponin, dan tanin pada daun sirih. Menurut Mursito (2002) melaporkan bahwa saponin dan tanin bersifat antiseptik pada luka atau infeksi permukaan yang disebabkan oleh bakteri dan jamur baik secara sistemik maupun superfisialis. Menurut Mangunwardoyo (2012) untuk mengetahui secara pasti, ekstrak bagian tanaman semestinya dilakukan identifikasi untuk mengetahui senyawa apa yang terkandung di dalamnya. Hal ini penting untuk mengetahui senyawa apa yang mendominasi dalam mempengaruhi pertumbuhan dan perkembangan suatu jamur yang digunakan untuk uji.

Tjitrosoepomo (2005) melaporkan bahwa dalam daun sirih terkandung minyak atsiri kurang lebih 30\% fenol, derivatnya adalah kavikol dan kavibetol yang bersifat antijamur yang diduga ada di dalam buah sirih hijau untuk menghambat pertumbuhan $C$ albicans. Hal yang sama dilaporkan Kartasapoetra (1992) bahwa daun sirih mengandung kavikol dan kavibetol yang merupakan turunan dari fenol yang mempunyai daya antibakteri lima kali lipat dari fenol biasa terhadap Staphylococcus aureus. Pelczar \& Chan (1986) mengungkapkan bahwa mekanisme fenol dalam membunuh mikroorganisme yaitu dengan cara mendenaturasi protein sehingga pertumbuhan jamur terhambat dan mati. Menurut Ingram (1981) senyawa fenol ini diduga membunuh jamur dengan cara merusak membran selnya, hal ini 
akan berakibat terjadinya kebocoran sel yang ditandai dengan keluarnya makromolekul seperti protein dan asam nukleat dari dalam sel sehingga terjadi kematian sel.

Jabarsyah et al. (2009) melaporkan bahwa senyawa fenol merupakan antimikroba yang bekerja meracuni protoplasma dengan cara merusak dan menembus dinding sel. Selanjutnya fenol akan menyebabkan protein sel mikroba rusak. Senyawa fenol juga dapat menonaktifkan enzim di dalam sel mikroba, mengubah tegangan permukaan, dan merusak permeabilitas selektif dari membran sel.

\section{KESIMPULAN}

Hasil penelitian menunjukkan bahwa ekstrak daun sirih hijau berpengaruh nyata terhadap penghambatan pertumbuhan C. albicans (ATCC 1805). Pada konsentrasi $10 \%$ perlakuan mampu menghambat zona pertumbuhan hingga 25,88 mm. Walaupun demikian, hasil pengamatan terhadap konsentrasi ini masih dapat meningkat mengingat adanya kecenderungan terhadap peningkatan aktivitas penghambatan dari perlakuan konsentrasi ekstrak yang digunakan. Hasil pengamatan ini menunjukkan bahwa ekstrak sirih hijau dapat digunakan sebagai antijamur C. albicans.

\section{DAFTAR PUSTAKA}

Adams, A., S. Kumar, M. Clauson, and S. Sahi. 2011. Antiyeast activities of Origanum oil against human pathogenic yeast. Advances in Bioscience and Biotechnology. 2: 103-107.

Agarwal, V., P. Lal, and V. Pruthi. 2008. Prevention of Candida albicans biofilm by plant oils. Mycopathologia. 165: 13-19.

Damayanti, R. M dan Mulyono. 2008. Kasiat dan manfaat daun sirih. Agromedia Pustaka. Jakarta.

Darmani, E.H. 2003. Hubungan antara pemakaian AKDR dengan kandidiasis Vagina di RSUD Dr. Pirngadi Medan. Bagian Ilmu Kulit dan Kelamin, Fakultas Kedokteran, USU. http:/ / repository.usu.ac.id/bitstream/123456789/6373 /1/kulit-endang.pdf. 29 hal.

Departemen Kesehatan (Depkes). 1988. Investaris Obat Indonesia Jilid 1. Balai Penelitian dan Pengembangan
Kesehatan. Departemen Kesehatan Republik Indonesia, Jakarta.

Doddanna, S.J., S. Patel, M.A. Sundarrao, and R.S. Veerabhadrappa. 2013. Antimicrobial activity of plant extracts on Candida albicans: an in vitro study. Indian Journal of Dental Research. 24(4): 401-45.

Effendy, L. 2013. Potensi antijamur kombinasi ekstrak etanol daun sirih merah (Piper crocatum Ruiz \& Pav.) dan kelopak bunga rosella (hibiscus sabdariffa Linn.) terhadap Candida albicans. Calyptra. 2(1): 1-10.

Erturk, O. 2006. Antibacterial and antifungal activities of ethanolic extracts from eleven spice plants. Biologia. 61(3): 275-278.

Gholib, D. dan E. Kusumaningtyas. 2007. Uji daya hambat ekstrak rimpang lengkuas dan daun sirih terhadap kapang dermatofit secara in vitro dan in vivo. Proseding Seminar Nasional Teknologi Peternakan dan Veteriner. Hal: 877-884.

Hermawan A., H. Eliyani dan W. Tyasningsih. 2007. Pengaruh ekstrak daun sirih (Piper betle L) terhadap pertumbuhan Staphylococus aereus dan Esherichia coli dengan metode difusi disk. Artikel Ilmiah. Universitas Airlangga. Surabaya.

Ingram, C.O. 1981. Mechanisme of lysis of E. coli by ethanol and other chaotropic agents. J Bacterial. 146: 331-335.

Jabarsyah, R., D. Rugian dan Arniati. 2009. Pengaruh ekstrak daun sirih terhadap pertumbuhan Vibrio sp. Jurnal Harpodon. 2(1): 24-30.

Jawetz, M., dan Adelberg. 2008. Mikrobiologi Kedokteran. Edisi 23. Cetakan 1. Buku Kedokteran. Jakarta.

Kartasapoetra, G. 1992. Budidaya Tanaman Berkhasiat Obat. Rineka Cipta. Jakarta. Hal: 25-26.

Kumalasari, E. dan N. Sulistyani. 2011. Aktivitas antifungi ekstrak etanol batang binahong (Anredera cordifolia Tenore) Steen) terhadap Candida albicans serta skrining fitokimia. Jurnal Ilmiah Kefarmasian. 1(2): 51-62.

Kuswadji, A. Djuanda, H. Mochtar, dan S. Aisah. 1999. Ilmu penyakit kulit dan kelamin. FK UI. Edisi Ketiga. Jakarta.

Mangunwardoyo, W., Deasywaty, and T. Usia. 2012. Antimicrobial and identification of active compound Curcuma xanthorrhiza Roxb. International Journal of Basic Applied Sciences. 12(1): 69-78.

Mursito, B. 2002. Ramuan tradisional untuk penyakit malaria. PT. Penebar Swadaya. Jakarta.

Pelczar, M.J. and E.C.S. Chan. 1986. Dasar-dasar mikrobiologi 1. Penterjemah: Ratna S. Hadioetomo dkk. Universitas Indonesia Press. Jakarta.

Ragu, G. 2010. Evaluation of antimicrobial potential of Piper (L) spesies. Departemen of Advance Zoologi and Biotecnology. NPT. 1(1): 21.

Rahmah, N dan A.K.N. Rahman. 2010. Uji fungistatik ekstrak daun sirih (Piper betle L.) terhadap Candida albicans. Biocientiae. 7(2): 17-24.

Reveny, J. 2011. Daya antimikroba ekstrak dan fraksi daun sirih merah (Piper betle Linn.). Jurnal Ilmu Dasar. 12(1): 612.

Siswandono dan Soekardjo. 1995. Kimia medisinal. Penerbit. Airlangga Universitas Press. Surabaya. 
Steel, R.G.D. dan J.H. Torrie. 1991. Prinsip dan prosedur statistika. PT Gramedia Utama, Jakarta.

Sulistijowati S, A. dan D. Gunawan. 1998. Efek ekstrak daun kembang bulan (Tithonia diversifolia A.Gray.) terhadap Candida albicans serta profil kromatografinya. Media Litbangkes. 8(3-4): 32-37.

Supreetha, S., S. Mannur, S.P. Simon, J. Jain, S. Tikare, and A. Mahuli. 2011. Antifungal activity of ginger extract on Candida albicans: an in vitro study. Journal of Dental Sciences and Research. 2(2): 1-5.

Syukur, C. dan Hermani. 1999. Budidaya tanaman obat tradisional. PT. Penebar Swadaya, Jakarta.
Thirach, S., K. Tragoolpua, and S. Punjaisee. 2003. Antifungal activity of some medicinal plant extracts against Candida albicans and Cryptococcus neoformans. Proc. Acta Hort. 217-221.

Tjitrosoepomo, G. 2005. Taksonomi tumbuhan obat-obatan. Gadjah Mada University Press. Yogyakarta.

Wahyuningtyas, E. 2008. Pengaruh ekstrak Graptophyllum pictum terhadap pertumbuhan candida albicans pada plat gigi tiruan resin akrilik. Indonesian Journal of Dentistry. 15(3): 187-191. 